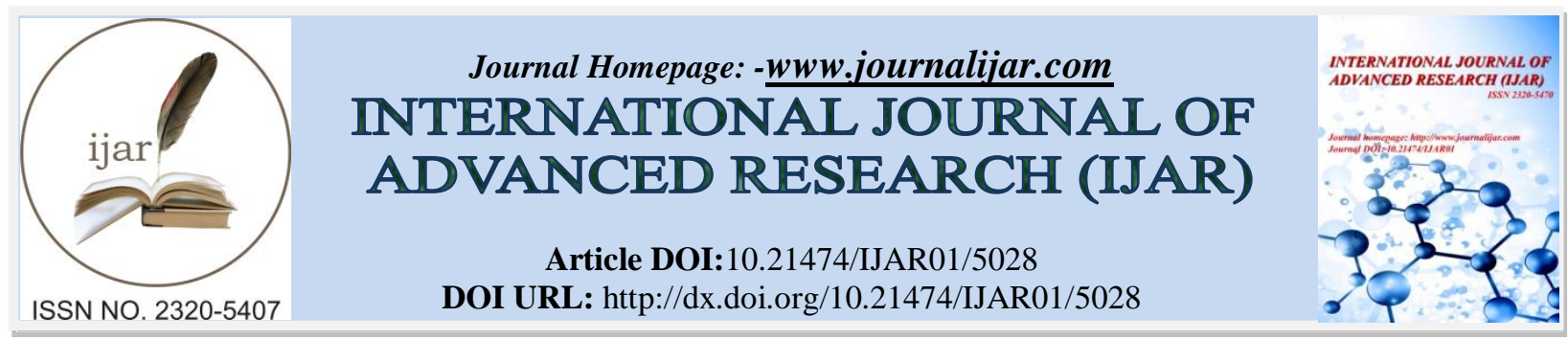

RESEARCH ARTICLE

\title{
EFFECT OF SMOKING ON LEVELS OF CALCIUM, MAGNESIUM AND BLOOD PARAMETERS IN PATIENTS WITH CHRONIC PERIODONTITIS.
}

1. M.D.S Periodontology, BBDCODS, Lucknow.

\section{Pavni Avasthy ${ }^{1}$ and Vivek Govila ${ }^{2}$.}

2. H.O.D Department of Periodontology, BBDCODS, Lucknow.

\section{Manuscript Info}

Manuscript History

Received: 01 June 2017

Final Accepted: 03 July 2017

Published: August 2017

\section{Keywords:-}

calcium, periodontitis, smoking, magnesium, CAL, PPD, aemoglobin concentration

\begin{abstract}
Background: Tobacco smoking is regarded as one of the most significant risk factors for the development and progression of periodontal disease. The purpose of this study was to evaluate and compare the effect of smoking on salivary composition of whole saliva and blood parameters in subjects with chronic periodontitis.

Materials and Methods: The study comprised of 40 subjects equally divided into 2 groups of non-smokers with chronic periodontitis and smokers with chronic periodontitis. Non-stimulated whole saliva and blood samples were obtained. Biochemical analysis of salivary total protein, calcium and magnesium was performed. Laboratory blood investigations included hemoglobin concentration.

Results: On biochemical analysis of whole saliva, calcium and magnesium were reduced in smokers with periodontitis to $3.47 \pm 1.49$ $\mathrm{mg} / \mathrm{dL}$ and $0.80 \pm 3.87 \mathrm{mEq} / \mathrm{L}$ Neo from $13.89 \pm 10.34 \mathrm{mg} / \mathrm{dL}$ and $1.26 \pm 0.90 \mathrm{mEq} / \mathrm{L} \mathrm{Neo}$, in non-smokers with periodontitis. The hemoglobin concentration, was lower in smokers with chronic periodontiits.

Conclusion: The present study exhibited reduced concentrations of calcium and magnesium in whole saliva in smokers with chronic periodontitis. Smoking also affects the RBC parameters in patients.
\end{abstract}

Copy Right, IJAR, 2017,. All rights reserved.

\section{Introduction:-}

Periodontitis comprises a group of inflammatory conditions of the supporting tissues of the teeth. These conditions are initiated by microorganisms and their products and modulated by the immunological response of the host (1). However, the manifestation and progression of periodontitis is influenced by a wide variety of determinants, including subject characteristics, social and behavioural factors, systemic factors, genetic factors, tooth level factors, microbial composition of dental plaque, and other emerging factors (2). Smoking is one of the major environmental risk factors for periodontal diseases. Studies suggest that cigarette smokers have significantly greater probing depths and bone loss $(3,4)$ with significantly fewer teeth $(5)$ and more supragingival calculus (6) than nonsmokers. It is widely accepted that smoking impairs the innate and immune host responses (7), which may have an impact on periodontal health (8). Various functions of oral or peripheral neutrophils including the phagocytosis (9), generation of superoxide and hydrogen peroxide (10), expression of integrin (11) and production of protease inhibitors (12) are negatively affected by smoking or to nicotine exposure. Alterations in gingival crevicular fluid, peripheral blood 
mononuclear cells, and the levels of various cytokines tipping the balance in favour of tissue breakdown have been noted in smokers $(13,14)$.

The diagnosis of periodontal disease usually accomplished through clinical periodontal parameters including periodontal pocket depth, and clinical attachment loss (CAL) (15).

Saliva, which plays an important role in the protection of periodontium, also is affected by smoking (16,17). Analysis of saliva can be contributed in the periodontal disease diagnosis (18). Saliva can be easily collected and it contains locally and systemically derived markers of periodontal diseases (19). The analysis of saliva may offer a cost-effective approach to assess periodontal disease incidence in large population (22).

Anemia of chronic disease is a cytokine mediated normocytic, normochromic, mild to moderate type of anemia in patients with acute or chronic immune activation (23). It is seen in patients with chronic infection, and inflammatory and/or neoplastic disorders despite the presence of adequate iron and vitamin stores (24). The condition is usually characterized by a low reticulocyte count indicating an underproduction of RBC (23). The aim of present study was to evaluate the effect of cigarette smoking on levels of calcium, magnesium and Haemoglobin concentration (Hb) in the subjects with chronic periodontitis.

\section{Materials and methods:-}

A total number of 40 patients were selected from the outpatient department, Department of Periodontics, Babu Banarasi Das College of Dental Sciences, Lucknow.

The inclusion criteria consisted of Patients within the age group of 35-50 years. Male patients who had smoked an average of $>10$ cigarettes/day for $>2$ years. Patients having chronic periodontitis defined as, minimum of 20 remaining teeth, with periodontal disease as evidenced by at least 4 tooth sites with probing pocket depth (PPD) $>4 \mathrm{~mm}$, clinical attachment level $(\mathrm{CAL})>2 \mathrm{~mm}$ and radiographic evidence of bone loss $>2 \mathrm{~mm}$ from the cementoenamel junction (CEJ). Patients with no contraindication to periodontal therapy.

The exclusion criteria consisted of cigar, pipe smokers and arecanut chewers. Patients suffering from chronic systemic illness like diabetes, hypertension, active infection etc. and taking medications for the same. Patients suffering from aggressive periodontitis, periodontal abscess, necrotizing ulcerative gingivitis or periodontitis. Patients who have received any periodontal treatment or antibiotics within the preceding 6 months and patients with known allergy or hypersensitivity to local anaesthetic agents.

The patients were divided into two groups. Group I : Non-smokers suffering from chronic periodontitis. Group II: Smokers suffering from chronic periodontitis.

\section{Sample collection for blood:-}

Blood sample collection and hematological investigations was done. Four milliliters of venous blood was collected by venepuncture from the antecubital fossa under aseptic conditions. The blood was then transferred immediately to the vial containing EDTA. The hematological investigation carried out were hemoglobin (Hb) (in gm\% by Sahli's method)

\section{Sample collection for saliva:-}

All the saliva samples were collected usually between 9 am and $11 \mathrm{am}$. Subjects were instructed not to consume any food or liquids $2 \mathrm{hrs}$ before sample collection. Non-stimulated saliva was collected from the oral cavity where it was allowed to accumulate at the floor of the mouth and was spat out in a sterile screw capped test tube during the collection period.

\section{Biochemical analysis:-}

Biochemical analysis for calcium and magnesium was done by using air - acetylene atomic absorption spectrophotometer.

The data obtained was analyzed by using SPSS 17software. One-way ANOVA (SPSS Inc., Chicago, IL, USA) was used to compare the data between the two groups, the values were expressed as mean and standard deviation, with significance being fixed at the level $0.05(\mathrm{P}<0.05)$. 


\section{Results:-}

A total of 40 males were included in the study and divided into groups I (20 nonsmokers) and II (20smokers).

The mean age of subjects in group I was $44.36 \pm 4.59$ while in group II it was $44 \pm 5.02$.

The hemoglobin concentration was found to be $13.76 \pm 0.78 \mathrm{gm} / 100 \mathrm{~mL}$ in group I, while it was $10.26 \pm 0.75$ $\mathrm{gm} / 100 \mathrm{~mL}$ in group II. The difference in hemoglobin concentration in groups I and II was found to be statistically significant $(\mathrm{P}<0.01)$.

The biochemical analysis of calcium and magnesium was reduced in patients who were smokers with periodontitis, as compared to non-smokers with periodontitis, the differences being statistically significant. Calcium and magnesium were reduced in smokers with periodontitis to $3.47 \pm 1.49 \mathrm{mg} / \mathrm{dL} \& 0.80 \pm 3.87 \mathrm{mEq} / \mathrm{L}$ Neo from $13.89 \pm 10.34 \mathrm{mg} / \mathrm{dL}$ and $1.26 \pm 0.90 \mathrm{mEq} / \mathrm{L}$ Neo respectively, in non-smokers with periodontitis.

Table 1:-

\begin{tabular}{|l|c|c|}
\hline \multicolumn{1}{|c|}{ PARAMETERS } & \multicolumn{1}{c|}{$\begin{array}{c}\text { GROUP I } \\
\text { Non smokers + CP }\end{array}$} & $\begin{array}{c}\text { GROUP II } \\
\text { Smokers + CP }\end{array}$ \\
\hline \multicolumn{1}{|c|}{ AGE } & $44.36+/-4.59$ & $44+/-5.02$ \\
\hline $\begin{array}{l}\text { POCKET PROBING DEPTH } \\
\text { (PPD) }\end{array}$ & $4.59+/-0.36^{*}$ & $4.98+/-0.36^{*}$ \\
\hline $\begin{array}{l}\text { CLINICAL ATTACHMENT } \\
\text { LOSS (CAL) }\end{array}$ & $4.95+/-0.58^{*}$ & $5.41+/-0.47^{*}$ \\
\hline $\begin{array}{l}\text { HAEMOGLOBIN } \\
\text { CONCENTRATION\%(Hb\%) }\end{array}$ & $13.76+/-0.78 \mathrm{gm} / 100 \mathrm{ml} * *$ & $10.26+/-0.76 \mathrm{gm} / 100 \mathrm{ml} * *$ \\
\hline CALCIUM (Ca) & $13.89+/-10.34 \mathrm{mg} / \mathrm{dl}$ & $3.47+/-1.49 \mathrm{mg} / \mathrm{dl}$ \\
\hline MAGNESIUM (Mg) & $1.26+/-0.90 \mathrm{mEq} / 1$ & $0.80+/-3.87 \mathrm{mEq} / 1$ \\
\hline
\end{tabular}

$* \mathrm{p}<0.01, * * \mathrm{p}<0.001$

\section{Discussion:-}

It is well documented that subjects with periodontitis are at an increased risk for systemic diseases like cardiovascular and cerebrovascular disease, chronic obstructive pulmonary disease, poor glycaemic control, and an adverse outcome of pregnancy (25-28). Recent reports also suggest a reduction in $\mathrm{Hb} \%$ and $\mathrm{RBC}$ count in subjects with chronic periodontitis. $(29,30)$. These facts indicate that periodontitis has an influence on systemic health. Although the exact mechanism is not known, it may occur through the raised plasma levels of inflammatory markers, such as interleukin 1 and 6 , tumor necrosis factor- $\alpha$, fibrinogen, acute phase proteins including C-reactive proteins, soluble cellular adhesion molecule, and cytokines, accounted in cases of periodontitis.(31-33). It is well established that cigarette smoking is the major preventable risk factor for periodontal disease(34). With a comparable amount of plaque, smokers show deeper probing depths (35), greater attachment loss (36), and more bone loss. Erdemir et al.(31)concluded that cigarette smoking may lead to anemia of chronic disease in subjects with chronic periodontitis.

The present study was carried out to evaluate the influence of cigarette smoking on the concentration of $\mathrm{Hb}$, calcium and magnesium in the subjects with chronic periodontitis. In the study it was observed that smokers have low levels $\mathrm{Hb} \%$, calcium and magnesium compared to non smokers.

The Calcium in saliva helps to prevent dissolution of dental enamel and help in remineralization phases. Calcium is the most efficient $\mathrm{pH}$ buffer for regulating the body fluids. It is present in whole saliva typically at $1.4 \mathrm{mmol} / 1$ in unstimulated saliva and $1.7 \mathrm{mmol} / 1$ in stimulated saliva $(39,40)$.

The Magnesium is a mineral that helps with the formation of teeth. It is present in whole unstimulated saliva at about $0.32 \mathrm{mmol} / 1$ and at $0.25 \mathrm{mmol} / 1$ in stimulated saliva $(39,40)$. Saliva exerts a major influence on plaque initiation, maturation and metabolism. Salivary flow and composition influence calculus formation, periodontal disease and caries. The inorganic components of plaque are predominantly calcium and phosphorous, with trace amounts of other minerals such as sodium and potassium. The source of inorganic constituents of supragingival plaque is primarily saliva; as the mineral content increases, the plaque mass becomes calcified to form calculus (41) 
Some of the inorganic components of calculus are calcium, phosphate, magnesium and trace elements of sodium. Early plaque of heavy calculus formers contains more calcium and less potassium than that of non-calculus formers. Zuabi et al. found that non-smokers exhibited distinct salivary composition, characterized with significantly smaller calcium, magnesium and sodium concentrations compared with nonsmokers (42).

\section{Conclusions:-}

Smokers with chronic periodontitis are associated with decreased levels of $\mathrm{Hb} \%$, calcium and magnesium, thus making them more prone to other systemic diseases and blood disorders caused as a result of anemia, poorer oral health due to high incidence of caries and periodontal diseases.

\section{References:-}

1. Hafajee AD, Socransky SS. Microbial and etiological agents of destructive periodontal disease. Periodontol 2000 1994; 5: 78111.

2. Nunn M. Understanding the etiology of periodontitis: an overview of periodontal risk factors. Periodontol 20002003; 32: 11-23.

3. Feldman RS, Bravacos JS, Rose CL. Associations between smoking different tobacco products and periodontal disease indexes. J Periodontol 1983;54: 481-7.

4. Bergstrom L, Eliasson S, Preber H. Cigarette smoking and periodontal bone loss. J Periodontol 1991; 62: 2426.

5. Calsina G, Ramon JM, Echeverria JJ. Effects of smoking on periodontal tissues. J Clin Periodontol 2002; 29: 771-6.

6. Bergstrom J. Tobacco smoking and supragingival dental calculus. J Clin Periodontol 1999; 26: 541-7.

7. Barbour SE, Nakashima K, Zhang JB et al. Tobacco and smoking: environmental factors that modify the host response (immune system). Crit Rev Oral Biol Med 1997; 8: 437-60.

8. Kinane DF, Chestnutt IG. Smoking and periodontal disease. Crit Rev Oral Biol Med 2000; 11: 356-65.

9. MacFarlane GD, Herzberg MC, Wolff LF, Hardie NA. Refractory periodontitis associated with abnormal polymorphonuclear Leukocyte phagocytosis and cigarette smoking. J Periodontol 1992; 63: 908-13.

10. Pabst MJ, Pabst KM, Collier JA et al. Inhibition of neutrophil and monocyte defensive functions by nicotine. $\mathbf{J}$ Periodontol 1995; 66: 1047-55.

11. Ryder MI, Fujitaki R, Lebus S et al. Alterations of neutrophil L-selectin and CD18 expression by tobacco smoke: implications for periodontal diseases. J Periodontal Res 1998; 33: 359-68.

12. Persson L, Bergstrom J, Ito H, Gustafsson A. Tobacco smoking and neutrophil activity in patients with periodontal disease. J Periodontol 2001; 72: 90-5.

13. Bostrom L, Linder LE, Bergstrom J. Smoking and crevicular fluid levels of IL-6 and TNF- $\alpha$ in periodontal disease. J Clin Periodontol 1999; 26: 352-7.

14. Ryder MI, Saghizadeh M, Ding Y, Nyugen N, Soskolne A. Effects of tobacco smoke on secretion of IL- 1b, TNF-a and TGF-b from peripheral blood mononuclear cells. Oral Microbiol Immunol 2002; 17: 331-3.

15. Inoue H, Ono K, Masuda W, Moremoto Y, Tanaka T, Yokota M. Gender difference in unstimulated whole saliva flow rate and salivary gland sizes. Arch Oral Biol 2008; 51:1055-60.

16. de Almeida P, Gregio A, Machado M, de Lima A, Azevedo L. Saliva Composition and Function :A Comprehensive review, The Journal of Contemporary Dental Practice 2008; 9(3):72-80.

17. Bortold P, Ishikawa I and De Deios N. Current trends in periodontal diagnosis, disease recognition and management.

18. Proceedings of the 5th Asian Pacific Society of Periodontology Meeting, Cebu. The Philippines, 2003.

19. Kaufman E, Lamster I. The Diagnostic Application of Saliva-A Review. CROBM 2002; 13 (2): $197-212$.

20. Lamster I. Antimicrobial mouthrinses and the management of periodontal diseases. JADA 2006; 137(3):5s-9s.

21. Sculley D, Langley-Evans M. Salivary antioxidants and periodontal disease status. The Nutritional Society 2002; 61:137- 41.

22. Aurer A, Jorgic-Srdjak K, Plancak D, Stavljenic-Rukkavina A, Aurer-Kozelj J. Proinflamatory factors in saliva as possible Markers for periodontal disease. Coll Antropol 2005; 29(2): 435-9.

23. Weiss G, Goodnough LT. Anemia of chronic disease (review article). N Engl J Med 2005; 352: $1011-23$.

24. Means RT, Krantz SB. Progress in understanding the pathogenesis of the anemia of chronic disease. J Am SocHematol 1992; 80: 1639-47.

25. Scannapieco FA. Position paper periodontal disease as a potential risk factor for systemic diseases. $\mathbf{J}$ Periodontol 1998; 69: 841-50. 
26. Beck JD, Garcia R, Heiss G, Vokonas P, Offenbacher S. Periodontal disease and cardiovascular disease. J Periodontol 1996; 67: 1123-37.

27. Taylor GW, Burt BA, Becker MP et al. Severe periodontitis and risk for poor glycemic control in patients with non-insulin dependent diabetes mellitus. J Periodontol 1996; 67: 1085-93.

28. Offenbacher S, Katz V, Fertik G et al. Periodontal infection as a possible risk factor for preterm low birth weight. J Periodontol 1996; 67(Suppl.10): 1103-13.

29. Hutter JW, Van der Velden U, Varoufaki AR, Huffels AM, HoekFJ,Loos BG. Lower numbers of erythrocytes and lower levels of haemoglobin in periodontitis patients compared to control subjects. J Clin Periodontol 2001; 28: 930-6.

30. Taylor BA, Tofler GH, Carey HMR et al. Full-mouth tooth extraction lowers systemic inflammatory and thrombotic markers of cardiovascular risk. J Dent Res 2006; 85: 74-8.

31. Erdemir EO, Nalcacib R, Caglayan O. Evaluation of systemic markers related to anemia of chronic disease in the peripheral blood of smokers and non-smokers with chronic periodontitis. Eur J Dent 2008; 2: 102-9.

32. Loos BG. Systemic markers of inflammation in periodontitis. J Periodontol 2005; 76: 2106-21.

33. Offenbacher S, Madianos PN, Champagne CM et al. Periodontitis-atherosclerosis syndrome: an expanded model of pathogenesis. J Periodontal Res 1999; 34: 346-52

34. Ebersole J, Machen RL, Steffen M.Willman D. Systemic acute-phase reactants, C-reactive protein and haptoglobin in adult periodontitis. Clin Exp Immunol 1997; 107: 347-52.

35. Grossi SG, Zambon JJ, Ho AW et al. Assessment of risk for periodontal disease. Risk indicators for attachment loss. J Periodontol 1994; 65: 260-7.

36. Bergstrom J, Eliasson S. Noxious effect of cigarette smoking on periodontal health. J Periodontal Res1987; 22: 513-7.

37. Buche J: The Calcium Connection. Herbs, Minerals and Goods web site. Monteral, Canada, (2004); 1 - 5.

38. Patrick P: Calcium. Report of London Laboratory Services Group, (2003); 1 -2.

39. Clark TJ: Calcium - Magnesium Formula. TJ Clark’s Secure Shopping Cart, (2004); 1 - 3.

40. Haake SK, Newman MG, Nisengard RJ, Sanz M. Periodontal Microbiology. IN : Newman MG, Takei HH, Carranza FA, editors.

41. Carranza’s Clinical Periodontology, Vol. 6 Philadelphia: WB Saunders; 2002. p. 96-112.

42. Zuabi O Machtei EE, Ben Aryeh H, Ardekian L, Peled M, Laufer D. The effect of smoking and periodontal treatment on salivary composition in patients with established periodontitis.J Periodontal 1999;70:1240-6. 